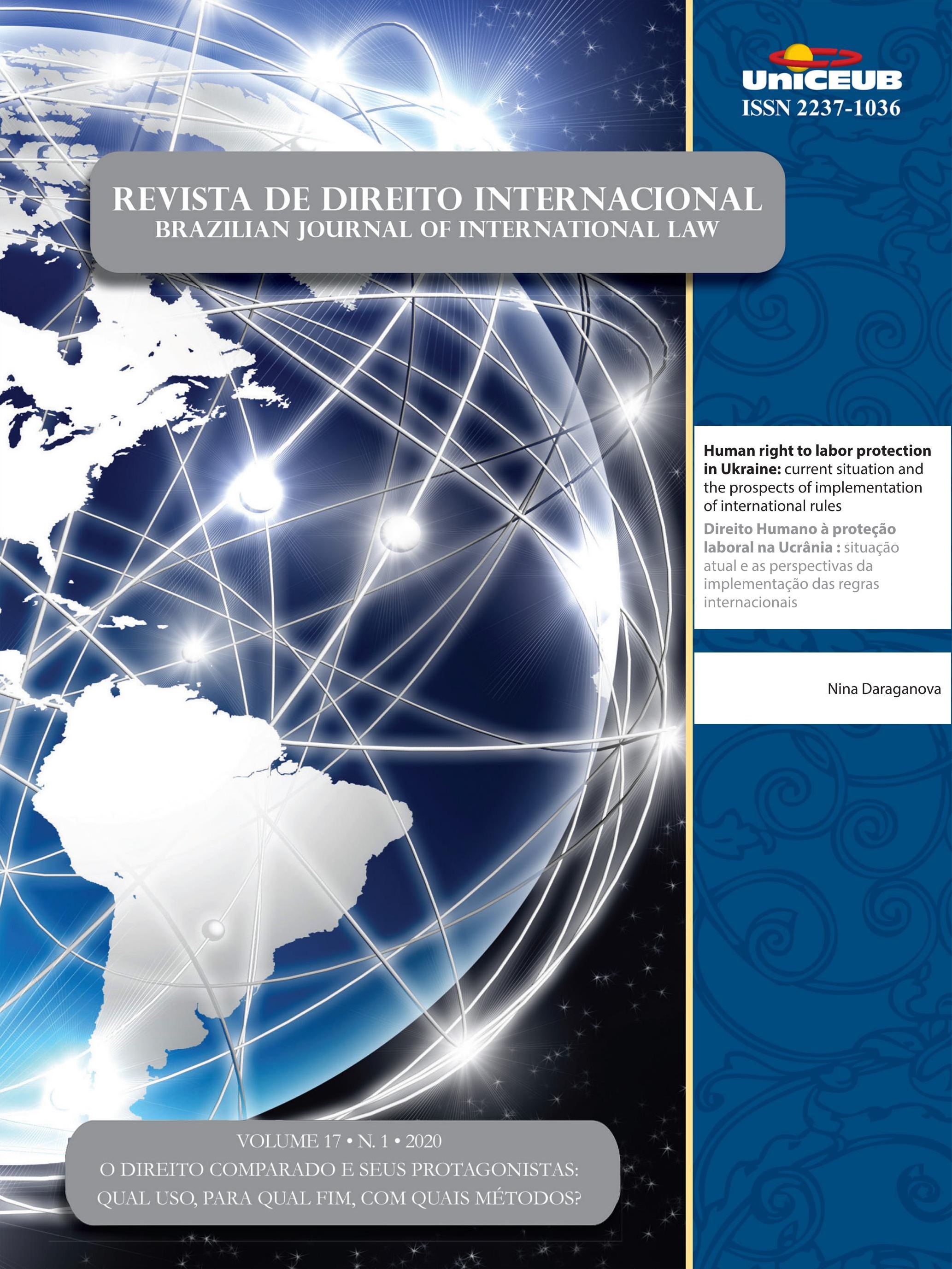


Parte I - O Direito comparado e seus Protagonistas: QuAL uso, PARA QUAL FIM, COM QUAIS MÉTODOS? .....................................................................1

EDITORIAL ............................................................................................................... 3

"Tudo o que precisamos fazer é ter certeza de que continuaremos conversando".............................. 3

Gustavo Cerqueira e Patrícia Perrone Campos Mello

Direito comparado E METOdologia $\quad$................................................... 6

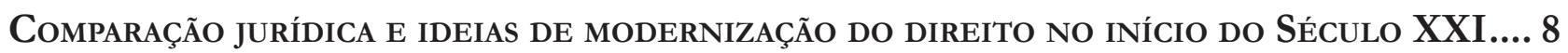
Gustavo Cerqueira

O DIREITO COMPARADO: ESFORÇO DE RESGATE HISTORIOGRÁFICO E DE PROBLEMAS METODOLÓGI$\cos$

Arnaldo Sampaio de Moraes Godoy e Gustavo Fereira Ribeiro

Direito Comparado e Política: Reflexões Necessárias .42

Raphael Carvalho de Vasconcelos e Deo Campos Dutra

Direito comparado no Brasil

L'originalité du Droit Brésilien et le Droit Comparé .57

Arnoldo Wald

LEI DA BOA RAZÃo E COMPARATISMO JURÍDICO NA DOUTRINA CIVILISTA BRASILEIRA DE 1850 A 1880

Alan Wruck Garcia Rangel

O STF EM REDE? QUANTO, COMO, COM QUE ENGAJAMENTO ARGUMENTATIVO O STF USA PRECEDENTES ESTRANGEIROS EM SUAS DECISÕES?

Patrícia Perrone Campos Mello e Felipe Meneses Graça 
Suprema Imprecisão: a metodologia em Direito Constitucional Comparado E as deficiênCias Em Seu uso pelo Supremo Tribunal Federal

Alonso Freire e Hugo Sauaia

Direitos comparados

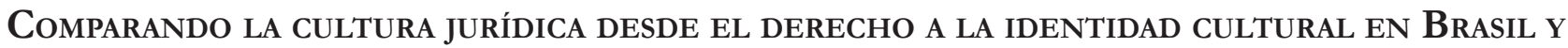

CHILE 145 Juan Jorge Faundes e Fabian Le Bonniec

O Divino e o Racional no Direito: notas para um diálogo entre sistemas jurídicos 181 Salem Hikmat Nasser e José Garcez Ghirardi

Regulação do discurso de Ódio: análise comparada em países do Sul Global 196 Jane Reis Gonçalves Pereira, Renan Medeiros de Oliveira e Carolina Saud Coutinho

Parte II - Outros temas

LA OTRA CARA DE LA MONEDA: PROTECCIÓN CONSTITUCIONAL DE LA EMPRESA, EL EMPRENDIMIENTO Y LA LIBRE COMPETENCIA EN CHILE y COLOMBiA

Juan Pablo Díaz Fuenzalida e Juan Sebastián Villamil Rodríguez

The European Court of Human Rights Decision on there 'Burqa Ban'and the CritiCal analysis of the Pragmatic experimental logic 258 Flavianne Fernanda Bitencourt Nóbrega e George Browne Rego

Direitos humanos das deslocadas ambientais e os impactos da Usina de Belo Monte: da EXPLORAÇÃO AMAZÔNICA À SUBJUGAÇÃO FEMININA

Thais Silveira Pertille e Letícia Albuquerque

Solução de Controvérsias em Acordos de Investimento: as experiênCias do CPTPP, CETA E DOS ACFIs

Fábio Morosini, Vivian Daniele Rocha Gabriel e Anastacia Costa

50 anos dos “direitos da Criança” na Convenção Americana de Direitos Humanos: a HISTÓRIA DO ARTIGO 19 311

Sven Peterke e Paloma Leite Diniz Farias 
EMPRESAS E DIREITOS HUMANOS: COMPARTILHANDO VALOR E RESPONSABILIDADES .325 Melina Girardi Fachin

CONTEMPORARY RESPONSES TO BUSINESSES' NEGATIVE HUMAN RIGHTS IMPACT 341 Andres Felipe Lopez

Human Right to LABOR PROTECTION IN UKRAINE: CURRENT SITUATION AND THE PROSPECTS OF IMPLEMENTATION OF INTERNATIONAL RULES 363 Nina Daraganova

International Regulation and Global Governance: The EU influential Method IN TIMES OF NORMATIVITY CHANGE 373 Gabriela Hühne Porto, Paula Wojcikiewicz Almeida e Juliana Maia F. A. Netto

Tecnologias digitais e o comércio de bens E SERviços na OMC/Digital. 391 Umberto Celli Junior

Los fuertes hacen lo QUe PUeden: exponiendo los límites de la Corte Penal InternaCIONAL .406

Cristián D. González-Ruiz e Víctor M. Mijares

Human Rights, Humanitarian Law and State Power 418 Renata Nagamine e João Roriz

Regional integration in the South Pacific: Challenges for Public governance .433 Joanna Siekiera

Parte III - Resenhas 443

RESENHA DA OBRA

“Democracia e policentrismo do poder", de Murilo Gaspardo 445 Angela Limongi Alvarenga Alves 


\title{
Human right to labor protection in Ukraine: current situation and the prospects of implementation of international rules*
}

\author{
Direito Humano à proteção laboral na \\ Ucrânia : situação atual e as perspectivas da \\ implementação das regras internacionais
}

Nina Daraganova**

\section{Abstract}

This article considered the right to labor protection as one of the most important human rights. The author analyzes the current state of protection of the right to labor protection in Ukraine and the prospect of implementation of international norms regulating this right. It is determined that the hallmark of the current stage of development of Ukraine is the exacerbation of problems related to human security and occupational safety. It is established that the situation regarding the presence of high levels of occupational injuries and occupational diseases in Ukraine is often a consequence of violations of the requirements of international legal acts on occupational safety. It is proved that today, one of the most difficult problems in Ukraine is bridging the gap between the legislation (both international and national) in the field of labor protection and their actual application. It is justified that official statistics do not reflect the real situation regarding human rights on labor protection in Ukraine. The author establishes the reasons for the absence in the official sources of real information about cases of injury to workers at the production. The role of labor inspectorate in Ukraine in the implementation of international labor protection standards has been determined.

keywords: Human rights. Labor protection. International labor protection.

* Recebido em 02/08/2019

Aprovado em 20/09/2019

** Nina Daraganova is Professor of the Department of Administrative, Financial and Information Law, Faculty of International Trade and Law, Kyiv National University of Trade and Economics. Doctor of science of Law. Expert on holding examination of draft laws of the Verkhovna Rada of Ukraine.

Email: ninadar095@gmail.com

\section{Resumo}

Este artigo considera o direito à proteção do trabalho um dos direitos humanos mais importantes. $\mathrm{O}$ autor analisa o estado atual da proteção do direito à proteção do trabalho na Ucrânia e a perspectiva de implementação de normas internacionais que regulam esse direito. Determinou-se que a marca do estágio atual de desenvolvimento da Ucrânia é a exacerbação de problemas relacionados à segurança humana e à segurança no trabalho. Está estabelecido que a situação relativa à presença de altos níveis de lesões e doenças ocupacionais na Ucrânia é frequentemente uma consequência das violações dos requisitos dos atos jurídicos internacionais sobre segurança no trabalho. Está provado que hoje, um dos problemas mais difíceis na Ucrânia é preen- 
cher a lacuna entre a legislação (internacional e nacional) no campo da proteção do trabalho e sua aplicação efetiva. Justifica-se que as estatísticas oficiais não refletem a situação real dos direitos humanos em matéria de proteção do trabalho na Ucrânia. O autor estabelece as razões da ausência nas fontes oficiais de informações reais sobre os casos de lesões aos trabalhadores da produção. Foi determinado o papel da inspeção do trabalho na Ucrânia na implementação das normas internacionais de proteção do trabalho.

Palavras-chave: Direitos humanos. Proteção laboral. Proteção laboral internacional

\section{Introduction}

The Constitution of Ukraine recognized a person, his life, health, honor, dignity, immunity and safety as the highest social value. All human rights, freedoms and their guarantees must determine the content and orientation of the activities of the state, and the state is responsible to the person for its activities ${ }^{1}$. One of the important places in the system of constitutional rights is the right of the citizen to work and proper, safe and healthy working conditions ${ }^{2}$ - namely the right to labor protection.

In Ukraine, the legal foundations for the realization of the right of workers to protect their life and health in the course of labor activity, to appropriate, safe and healthy working conditions, were laid down by the Law of Ukraine "On Labor Protection" adopted in October $1992^{3}$

\footnotetext{
1 Article 3 of The Constitution of Ukraine (UKRAINE. [Constitution (1996)]. The Constitution of Ukraine, June 28, 1996 № 254к/96-BP. Available at: https://zakon.rada.gov.ua/laws/ show $/ 254 \% \mathrm{D} 0 \% \mathrm{BA} / 96-\% \mathrm{D} 0 \% \mathrm{~B} 2 \% \mathrm{D} 1 \% 80$ ?lang=en. Accessed: 9 Jun. 2019.)

2 Article 43 of The Constitution of Ukraine (UKRAINE. [Constitution (1996)]. The Constitution of Ukraine, June 28, 1996 № 254к/96-BP. Available at: https://zakon.rada.gov.ua/laws/ show $/ 254 \% \mathrm{D} 0 \% \mathrm{BA} / 96-\% \mathrm{D} 0 \% \mathrm{~B} 2 \% \mathrm{D} 1 \% 80$ ?lang=en. Accessed: 9 Jun. 2019.)

3 The law defines: the foundations and principles of the state policy of Ukraine in the field of labor protection, including: the priority of the life and health of workers and the employer's full responsibility for creating appropriate, safe and healthy working conditions; raising the level of industrial safety by providing full technical control over the state of production, technology and products, assisting enterprises in creating safe and harmless working conditions; social protection of workers and full compensation for harm to persons who suffered from industrial accidents and occupational diseases,
}

However, the current stage of Ukraine's development is exacerbated by problems related to human security and labor protection. The texts of the acts of the current legislation on labor protection still contain a considerable number of outdated, ambiguous, contradictory and inconsistent legal norms, which is a violation of the requirement of systematic legal legislation.

However, particular concern is the high level of occupational injuries and occupational diseases, which is one of the main indicators of labor protection. In particular, according to the Federation of Trade Unions of Ukraine, over the past 10 years, the number of employees in conditions that do not meet the established standards on labor protection has doubled and amounts to more than 3 million workers ${ }^{4}$.

The high level of occupational injury and occupational disease in Ukraine is often a consequence of violations of international legal requirements on labor protection and leads to a wide variety of legal studies in this field and attempts to identify ways to address these problems.

At the same time, as M. Anufriev rightly pointed out, the problem of human rights and their protection belongs, of course, to the global ones, which have been solved by mankind for centuries. The human community has had to go a long and complicated way in order to understand the full meaning of human rights and freedoms, to conclude that human beings are the highest social value ${ }^{5}$. To a full extent, the same applies to ensuring that citizens exercise their rights to labor protection in accordance with the requirements of international instruments.

etc. (UKRAINE. Law of Ukraine, October 14, 1992 № 2694-XI. On Labor Protection. Available at: https://zakon.rada.gov.ua/laws/ show/2694-12?lang=en. Accessed: 9 Jun. 2019).

4 ABOUT the results of the consideration of the round table recommendations of 10 february 2015. Information and Analytical Center of the Federation of Trade Unions of Ukraine. Available at: http://www.fpsu.org.ua/napryamki-diyalnosti/pravovij-zakhist/ 6990-pro-rezultati-rozglyadu-rekomendatsij-kruglogo-stolu. Accessed: 9 Jun. 2019.

5 For more details see: АНУФРІЄВ, М. І. Зміцнення дисципліни і законності як фактор Аотримання прав і свобод громадян у службовій діяльності працівників ОВС. Вісник Харківського науіонального університету внутрішніх справ. п. 11, с. 9-12, 2000. 


\section{Human right to labor protection in Ukraine - analysis of the current situation}

Ukraine is Member of International Labor Organization (ILO) since 12.05.1954. As of January 1, 2019, Ukraine has ratified 71 of the 189 Conventions of International Labor Organization, including 8 out of 8 Fundamental conventions, 4 out of 4 Governance conventions and 59 of 177 Technical conventions ${ }^{6}$.

In accordance with Article 9 of The Constitution of Ukraine, the existing international treaties, the consent of which has been given by the Verkhovna Rada of Ukraine, are part of the national legislation of Ukrai$n^{7}$. The Labor Code of Ukraine stipulates that if an international treaty or international agreement in which Ukraine participates establishes rules other than those contained in the labor law of Ukraine, then the rules of an international treaty or international agreement apply ${ }^{8}$. Thus, both of The Constitution of Ukraine and The Labor Code of Ukraine enshrined the principle of priority of international legal norms over those of national law.

However, today, one of the most difficult proble$\mathrm{ms}$ in Ukraine (unfortunately not only in the context of consideration of the right to labor protection) is bridging the gap between current national and international regulations and their actual application. Standards do not become a general rule of conduct, but only a desirable, but often rather far-reaching, guideline. Therefore, the implementation of these norms is one of the most problematic issues.

We agree that this declaration of norms, this practical inactivity of some constitutional provisions on the right of labor protection of have their deep objective reasons and grounds. Constitutional and legal principles

INTERNATIONAL LABOR ORGANIZATION. Ratified conventions. Available at: https://www.ilo.org/gateway/faces/ home $/$ ctryHome?locale $=$ EN\&countryCode $=$ UKR\&_adf.ctrlstate $=$ qf3x0c73a_9. Accessed: 12 Jun. 2019.

Article 9 of The Constitution of Ukraine (UKRAINE. [Constitution (1996)]. The Constitution of Ukraine, June 28, 1996 № 254א/96-BP. Available at: https://zakon.rada.gov.ua/laws/ show $/ 254 \% \mathrm{D} 0 \% \mathrm{BA} / 96-\% \mathrm{D} 0 \% \mathrm{~B} 2 \% \mathrm{D} 1 \% 80$ ?lang=en. Accessed: 9 Jun. 2019).

Article 8-1 The Labor Code of Ukraine (UKRAINE. The Labor Code of Ukraine, on December 10, 1971 № 322-VII. Available at: https://zakon.rada.gov.ua/laws/show/322-08?lang=en. Accessed: 9 Jun. 2019). (in human and civil rights, freedoms, foundations of civil society, rule of law, etc.) formulated in independent Ukraine are characteristic of a well-formed democratic system and can be implemented in the conditions at least, developed bourgeois society and the state. Nevertheless, in a post-socialist country such conditions are absent. This creates a significant gap between the relevant constitutional provisions and the actual reality. And the chosen course of transformation has so far led to rather underdeveloped socio-economic, political and legal forms and relations?.

Consideration of the current state of legal support for labor protection in Ukraine requires careful analysis of statistics related to the level of occupational injuries and occupational diseases in Ukraine, as these indicators are one of the main indicators of the state of labor protection in the country. According to Y. Zaloznova and I. Brag, there are in general only two main types of occupational health risks for workers due to working conditions, first, the risk of occupational injury, and second, the risk of occupational disease ${ }^{10}$.

Indeed, occupational accidents and occupational diseases have been and remain a major social problem, causing the largest widespread socio-economic losses, occupational injury rates remain the most important characteristic of labor protection management ${ }^{11}$.

\subsection{Official information on the status of occupational injuries}

Official statistical information on the status of occupational injuries and occupational diseases in Ukraine is accumulated and generalized by the Social Insurance Fund of Ukraine ${ }^{12}$ and the State Service of Ukraine on

For more information see: НЕРСЕСЯНЦ В. С. Юрисnрудениия. Введение в курс общей теории права и государства: А^я юридических вузов и факультетов. Москва: НОРМАИНФРА·М, 1998. 288 с.

10 More information on this subject see: $3 А \wedge$ ОЗНОВА, Ю. С., Брага I. Г. Оцінка стану охорони та безпеки праці й соціальноекономічних насліАків їх незабезпечення у вугільній промисловості України. Економіка промисловості. п. 2, с. 271-279, 2011.

${ }_{11}$ For more information see: КРУЖИАКО О. Є. Наукові засади оперативного управління охороною прачі: автореф. Аис. ... АОкт. техн. наук: 05.26.01. Київ, 2011. с. 5.

12 Thus, according to Article 9 of the Law of Ukraine "On Amendments to Certain Legislative Acts of Ukraine on Reforming the Compulsory State Social Insurance and Legalization of the Wage Fund" of December 28, 2014, the main objectives of the Social Insurance Fund of Ukraine are: 
Labor $^{13}$ - the central body of executive power implementing state policy in the field of labor protection.

Thus, according to the official data of the Social Insurance Fund of Ukraine, in 2014, the working bodies of the Executive Directorate of the Fund registered 6 850 (of which 525 were fatal) victims of industrial accidents and 4352 occupational diseases. In 2014, compared to 2013, the number of insurance accidents decreased by $25.7 \%$ (from 9221 to 6850 ), the number of fatalities decreased by $0.6 \%$ (from 528 to 525), and the number of occupational diseases decreased by $25.7 \%$ or by 1,509 cases (from 5,861 to 4,352$)^{14}$. And comparing this number of victims with 2012 data, when the Social Insurance Fund of Ukraine received 12,907 reports of industrial accidents involving 13,313 people (including 1766 fatalities) ${ }^{15}$, these statistics show a decrease in the number of accidents in production for two years almost doubled.

An even more consistent tendency to reduce the number of industrial accidents (or at least to stabilize them) is observed when comparing the above data with the data for 2015-2018. In particular, in 2018 there were 4805 industrial accident victims, in $2017-4965$, in 2016 - 4 766, and in $2015-4592^{16}$.

Some scholars, such as O. Sorochinskaya, also point out that since Ukraine gained independence, there has

"1) implementation of state policy in the fields of social insurance against industrial accident and occupational disease that caused disability, in connection with temporary disability, health insurance;

2) provision of material security, insurance payments and social services;

3) accident prevention;

4) attribution of the policyholder to the class of professional risk of production taking into account the type of its economic activity; 5) carrying out checks of the reliability of the information provided by the insurers on the types of economic activity (including the main one) of enterprises, institutions and organizations, regardless of the form of ownership, type of activity and management in order to classify the insurer in the class of professional risk of production taking into account the type of its economic activity etc.".

13 UKRAINE. Cabinet of Ministers of Ukraine. Regulations on the State Service of Ukraine on Labor, n, 96, February 11. Available at: https://zakon.rada.gov.ua/laws/show/96-2015-\%D0\%BF?lang=en. Accessed: 9 Jun. 2019.

14 ANALYSIS of industrial accidents and occupational diseases in 2014 in Ukraine. Social Insurance Fund of Ukraine. Available at: http://www.social.org.ua. Accessed: 10 Jun. 2019.

15 ANALYSIS of industrial accidents and occupational diseases in 2012. Social Insurance Fund of Ukraine. Available at: http://www. social.org.ua. Accessed: 10 Jun. 2019.

16 ANALYSIS of industrial accidents and occupational diseases for 2015-2018. Social Insurance Fund of Ukraine. Available at: http://www.social.org.ua. Accessed: 10 Jun. 2019. been a steady tendency to reduce occupational injuries, both general and fatal. This thesis author is supported by the following statistics: in 1990, there were 139,600 cases of injuries (including 2640 with fatalities); in 1995 - 80450 (2 195 - with fatal consequences); 1999 - 39 844 (1 388 - lethal), in 2003 - 24929 (1 230 - lethal); 2007 - 18982 (925 - lethal), and in 2010 - 12242 (535 - lethal ${ }^{17}$.

Based on the analysis of the above data, one could conclude that there is a stable tendency to reduce both cases of occupational injuries and occupational diseases in Ukraine, and therefore the effective functioning in the country of the mechanism of legal protection of human rights for labor protection.

\subsection{The current state of human rights for labor protection in Ukraine}

However, the above official statistics do not reflect the true situation of human rights in the field of labor protection in Ukraine. In support of this view, we present the following arguments.

The transformations taking place in modern Ukraine inevitably impose their imprint on both its entire legal system and on such a vital field as labor protection. At the same time, at the present stage of its development, Ukraine has faced aggravation of problems in this area. According to the data of public control exercised by the trade union organizations of the Federation of Trade Unions of Ukraine, in 2014, 699 thousand workers were violated labor and socio-economic rights, which is twice more than in 2013. And in the last 10 years the workers who are working in conditions that do not meet the requirements the established safety standards have doubled to over 3 million. In 2013 of employees worked in poor sanitary and hygienic conditions: in the mining industry - $71 \%$; in the metal industry - 53\%; chemical industry - $41 \%$; in the energy sector $-33 \%{ }^{18}$.

Therefore, some employers are not prepared to create working conditions that meet the established re-

\footnotetext{
For more information see: СОРОЧИНСЬКА О. $\Lambda$. Стан охорони прачі в Украйні та заходи для ї̈ поліпмення. Збірник наукових праць Аержавного економіко-технологічного університету транспорту. Сер.: Транспортні системи і технології. Вип. 24. С. 240-247. 2014. 18 INFORMATION and Analytical Center of the Federation of Trade Unions of Ukraine. Available at: http://www.fpsu.org.ua/ napryamki-diyalnosti/pravovij-zakhist/6990-pro-rezultati-rozglyadu-rekomendatsij-kruglogo-stolu. Accessed: 10 Jun. 2019.
} 
quirements for labor protection (including international legal standards) and to carry out real preventive work on occupational safety. On the contrary, in the event of an accident, they try to hide this case.

This fact influences the level of officially recorded industrial accidents, which in turn causes significant differences between the real state of labor protection in Ukraine and the positive, encouraging information provided by the Social Insurance Fund of Ukraine ${ }^{19}$. It also follows from the information provided by the trade unions that non-governmental organization, through public scrutiny, can significantly assist state institutions in exercising their powers in the field of labor protection.

In addition, the Fund itself noted in the preamble to the Analysis of Industrial Accident and Occupational Diseases that a comparative analysis of the status of these cases and occupational diseases was made without taking into account those accidents and occupational diseases that occurred at the enterprises located in the settlements at the territories of which state authorities temporarily do not exercise or do not fully exercise their powers ${ }^{20}$. That is, since 2015, and up to the present, due to objective circumstances, official statistics do not include all accidents and occupational diseases in Ukraine ${ }^{21}$.

It should also be noted that the analysis of official statistics shows that the number of fatalities in case of industrial accidents has increased significantly in Ukraine.

Thus, at the parliamentary hearings on the state of

\footnotetext{
19 For more information see: ААРАГАНОВА, Н. В. Сучасний стан иравової освіти у сфері управління охоронон прачі в Украйні. Правова освіта в Украйні: еволюція, сучасний стан, перспективи розвитку: матеріали науково-практичної конференції. Київ: Академія адвокатури України, 2017. Available at: https://sites.google.com/ my.aau.edu.ua/conf-27-04-2017/матеріали/матеріали-частина-5. Accessed: 10 Jun. 2019.

20 ANALYSIS of industrial accidents and occupational diseases in 2015. Social Insurance Fund of Ukraine. Available at: http://www. social.org.ua. Accessed: 10 Jun. 2019.

21 In 2014, compared to 2013, the number of employed population decreased by 1 million 200 thousand people. According to expert estimates alone, 800,000 jobs have been lost in the Donetsk region alone. Having lost their jobs and ended up in the epicenter of hostilities, 1 million 345,000 Ukrainians were forced to flee their homes. It is the largest internal movement of citizens in the history of independent Ukraine. (PRESENTATION of the Employment Service Reform of June 26, 2015. Available at: http://tsn. ua/groshi/derzhava-pracevlashtovuvatime-ukrayinciv-po-novomuprezentaciya-reformi-sluzhbi-zaynyatosti-445971.html. Accessed: 10 Jun. 2019).
}

industrial safety and labor protection in 2010, it was noted that the ratio of accidents with fatalities to the number of occupational injuries has increased from 21 cases to 55 cases since 1992. At the same parliamentary hearings, it was reported that in Ukraine every 18th injury case is a fatal case, and it does not correspond to the existing laws in the world (according to the International Labor Organization, the average ratio is: 1 death 763 injured $)^{22}$.

On the other hand, the current level of injury in Ukraine indicates that a significant number of cases of injury to workers with mild and moderate severity are simply hidden from the investigation by employers, and therefore not accounted for. The mass concealment of cases of injury to workers at work or their transfer to the non-production category exempts the employer from carrying out effective preventive measures at the enterprise, and the Social Insurance Fund of Ukraine releases from compensation for the damage caused to the life and health of the victims.

\subsection{Reasons for the absence of completeness of information in the official sources on the cases of injuries in the workplace}

The lack of actual information on cases of injury to workers at work is a serious problem for Ukraine and occurs, we believe, for several main reasons:

1) concealment by employers of industrial injury cases from officials of the Social Insurance Fund of Ukraine - only fatal injuries are really difficult to conceal and not investigate. The correctness of this conclusion is confirmed by scientific research ${ }^{23}$;

2) transfer of industrial injury cases to the non-production accident category;

22 For more information see: XOXОТВI О. I. Стенограма виступу на Парламентських слуханнях від 17 мистопада 2010 р. «Про стан промислової безпеки та охорони праці». Available at: http:// static.rada.gov.ua/zakon/skl6/11session/par_sl/sl1711110.htm. Accessed: 10 Jun. 2019.

23 Ukraine is now a country where only serious and fatal accidents are actually recorded, and potentially dangerous cases are only recorded in single companies, mainly with foreign investments. And in the absence of real data on Ukraine, it is impossible to establish the correlation between dangerous events, minor injuries and injuries with serious consequences... (Богданова О. В. Проблеми використання теорії піраміди травматизму для запобігання нещасним випадкам на виробничтві. Проблеми охорони прачі в Украӥні збірник наукових прачь. Київ: $\triangle Y$ «Національний науково-АосліАний інститут промислової безпеки та охорони праці», Вип. 29. 2015. С. 43.). 
3) the presence of a large number of people working under civil agreements or without any documents at all ${ }^{24}$, therefore, deprived of the right to labor protection, including state guarantees in case of injury or death;

4) in the territories of Donetsk and Lugansk regions controlled by Ukraine, in the context of conducting an anti-terrorist operation, the procedure of investigation of accidents and causes of occupational diseases is delayed;

5) the introduction in Ukraine of a moratorium on inspections by inspectors of the State Service of Ukraine on Labor, which operated from 2015 to 2018.

\section{The role of the national labor inspection in the implementation of international labor standards}

One of the key elements of the system of state administration of labor protection in Ukraine is the State Service of Ukraine on Labor. It is this state authority that is tasked with implementing the state policy in the fields of industrial safety, labor protection, occupational health, handling explosive materials for industrial purposes, carrying out state mining supervision, as well as on the supervision and control of compliance with labor legislation, etc. ${ }^{25}$.

The legal status of this body is established primarily by the norms of The Constitution of Ukraine (Articles $3,6,8,9,13,19,22,24,26,27$, etc.). A significant amount of authority of the State Service of Ukraine on Labor is determined by a number of international acts. A special place among them belongs to the ILO Conventions, and above all: Labor Inspection Convention, 1947 (No. 81), Labor Inspection (Agriculture) Convention, 1969 (No. 129) and Labor Inspectorates (Non-Metropolitan Territories) Convention, 1947 (No. 85) ${ }^{26}$.

\footnotetext{
${ }^{24}$ For more information see: УКРАЇНЕЦЬ С. Я. Стенограма виступу на Парламентських слуханнях від 17 листопада 2010 p. «Про стан промислової безпеки та охорони праці». Available at: http://rada.gov.ua/zakon/skl6/11session/par_sl/sl1711110.htm. Accessed: 10 Jun. 2019.

25 Item 3 UKRAINE. Cabinet of Ministers of Ukraine. Regulations on the State Service of Ukraine on Labor, Resolution of the, February 11, 2015 № 96. Available at: https://zakon.rada.gov.ua/laws/show/962015-\%D0\%BF?lang=en. Accessed: 9 Jun. 2019.

26 INTERNATIONAL LABOR ORGANIZATION. Labour Inspection Convention, n. 81, 1947. Available at: https://www.ilo.org. Ac-
}

Thus, in accordance with the requirements of Article 3 of Convention No. 81 the functions of the system of labor inspection in Ukraine is included: (a) to secure the enforcement of the legal provisions relating to conditions of work and the protection of workers while engaged in their work, such as provisions relating to hours, wages, safety, health and welfare, the employment of children and young persons, and other connected matters; (b) to supply technical information and advice to employers and workers concerning the most effective means of complying with the legal provisions (possibly except point (c).

Ukrainian inspectors, secured by appropriate documents confirming their authority, have the right: (a) to enter freely and without previous notice at any hour of the day or night any workplace liable to inspection; (b) to enter by day any premises which they may have reasonable cause to believe to be liable to inspection; and (c) to carry out any examination, test or enquiry which they may consider necessary in order to satisfy themselves that the legal provisions are being strictly observed, and in particular (i) to interrogate, alone or in the presence of witnesses, the employer or the staff of the undertaking on any matters concerning the application of the legal provisions; (ii) to require the production of any books, registers or other documents the keeping of which is prescribed by national laws or regulations relating to conditions of work, in order to see that they are in conformity with the legal provisions, and to copy such documents or make extracts from them; (iii) to enforce the posting of notices required by the legal provisions; (iv) to take or remove for purposes of analysis samples of materials and substances used or handled, subject to the employer or his representative being notified of any samples or substances taken or removed for such purpose ${ }^{27}$.

In addition, labor inspectors have the right to take action to address deficiencies found on the structure, equipment or working methods, if such deficiencies are such as to endanger the health or safety of workers ${ }^{28}$.

cessed: 12 Jun. 2019., INTERNATIONAL LABOR ORGANIZATION. Labour Inspection (Agriculture) Convention, n. 129, 1969. Available at: https://www.ilo.org. Accessed: 12 Jun. 2019., INTERNATIONAL LABOR ORGANIZATION. Labour Inspectorates (Non-Metropolitan Territories) Convention, n. 85, 1947. Available at: https://www.ilo. org. Available at: https://www.ilo.org. Accessed: 12 Jun. 2019.

${ }_{27}$ Article 12 (INTERNATIONAL LABOR ORGANIZATION. Labour Inspection Convention, n. 81, 1947. Available at: https://www.ilo. org. Accessed: 12 Jun. 2019.)

28 Article 13 of the Convention No. 81 (INTERNATIONAL LA- 
It should be noted that in addition to the sufficiently broad rights granted to labor inspectors, labor inspectors must also carry out a considerable amount of duties. Labor inspectors: (a) shall be prohibited from having any direct or indirect interest in the undertakings under their supervision; (b) shall be bound on pain of appropriate penalties or disciplinary measures not to reveal, even after leaving the service, any manufacturing or commercial secrets or working processes which may come to their knowledge in the course of their duties; and (c) shall treat as absolutely confidential the source of any complaint bringing to their notice a defect or breach of legal provisions and shall give no intimation to the employer or his representative that a visit of inspection was made in consequence of the receipt of such a complaint ${ }^{29}$.

The above international standards are fully applicable to labor inspection in Ukraine.

However, there are serious risks to the effective exercise of authority by labor inspectors in Ukraine. We split these risks into two main groups.

The first group should include obstacles to the effective exercise of the powers of labor inspectors of "intra-national character". Analyzing the information of the National Institute for Strategic Studies ${ }^{30}$, such obstacles include: 1) overworking of labor inspectors; 2) limited human resources; 3 ) insufficient logistical support of the State Service of Ukraine on Labor and lack of necessary technical means for the daily work of inspectors; 4) modest wages of labor inspectors; 5) limited career opportunities for labor inspectors; 6) lack of proper qualification of labor inspectors.

The analysis of information by the International Labor Organization allowed the second group of risks to be classified as "obstacles to the effective exercise of the powers of labor inspectors of an international nature". That is, risks that directly or indirectly affect the effective func-

BOR ORGANIZATION. Labour Inspection Convention, n. 81, 1947. Available at: https://www.ilo.org. Accessed: 12 Jun. 2019.)

29 Article 5 (INTERNATIONAL LABOR ORGANIZATION. Labour Inspectorates (Non-Metropolitan Territories) Convention, n. 85, 1947. Available at: https://www.ilo.org. Available at: https://www.ilo.org. Accessed: 12 Jun. 2019.).

30 NATIONAL INSTITUTE FOR STRATEGIC STUDIES. Щодо віАповіАності об'єАнання Аержавної інспекції України 3 питань праці та Аержавної служби зайнятості України стандартам міжнародної організації праці /. Available at: http:/ / www.niss.gov.ua/articles/1341. Accessed: 12 Jun. 2019. tioning of labor inspections worldwide and affect not only Ukraine.

These include: 1) an increase in the number of small enterprises, which is increasingly difficult to effectively monitor; 2) the continuing tendency among enterprises to be created only for a short period of time, to change their legal form and owners, and great geographical mobility of enterprises (both nationally and internationally); 3) worldwide growth of various forms of "shadow economy"; 4) the emergence of "virtual" enterprise networks and the emergence of "virtual" employers, mini-employers (it is very difficult for labor inspectors to keep them in view and influence their activities); 5) increase in the number of atypical employment relationships; 6) increase in the number of employees working for several employers at once; 7) the presence of stressful situations caused by work; 8) reducing the number of trade union members, especially related to the fragmentation of labor in small businesses; 9) in return for industrial risks, the arrival of new threats to the health of workers, such as biochemicals, nanotechnologies, etc.

Ukraine has already faced some of the risks of the second group, for example, such as: an increasing number of small enterprises where it is increasingly difficult to carry out state surveillance (control): large geographical mobility of enterprises; the presence of "shadow" work. As for the other risks of the second group (for example, the emergence of "virtual" enterprise networks and "virtual" employers), then our country may still have to deal with them. In any case, the question of introducing reliable legal mechanisms and means of legal regulation of these forms arises before the national legal science today.

Summarizing the above, it should be noted that the right to labor protection is one of the most important in the human rights system. Only a conceptual and radical change in the paradigm of legal securing of this right in Ukraine will contribute to the real realization by citizens of their constitutional right to labor protection and can positively affect the production and economy of the country as a whole. Today, the issue of real implementation of fundamental international norms aimed at the true and effective realization of the right to labor protection by Ukrainian citizens is put on the agenda. 


\section{References}

ABOUT the results of the consideration of the round table recommendations of 10 february 2015. Information and Analytical Center of the Federation of Trade Unions of Ukraine. Available at: http://www.fpsu.org. ua/napryamki-diyalnosti/pravovij-zakhist/6990-prorezultati-rozglyadu-rekomendatsij-kruglogo-stolu. Accessed: 9 Jun. 2019.

ANALYSIS of industrial accidents and occupational diseases for 2015-2018. Social Insurance Fund of Ukraine. Available at: http://www.social.org.ua. Accessed: 10 Jun. 2019.

ANALYSIS of industrial accidents and occupational diseases in 2014 in Ukraine. Social Insurance Fund of Ukraine. Available at: http://www.social.org.ua. Accessed: 10 Jun. 2019.

ANALYSIS of industrial accidents and occupational diseases in 2012. Social Insurance Fund of Ukraine. Available at: http://www.social.org.ua. Accessed: 10 Jun. 2019.

ANALYSIS of industrial accidents and occupational diseases in 2015. Social Insurance Fund of Ukraine. Available at: http://www.social.org.ua. Accessed: 10 Jun. 2019.

INFORMATION and Analytical Center of the Federation of Trade Unions of Ukraine. Available at: http:/ /www.fpsu.org.ua/napryamki-diyalnosti/pravovij-zakhist/ 6990-pro-rezultati-rozglyadu-rekomendatsij-kruglogo-stolu. Accessed: 10 Jun. 2019.

INTERNATIONAL LABOR ORGANIZATION. Ratified conventions. Available at: https://www.ilo.org/ gateway $/$ faces $/$ home $/$ ctryHome?locale $=$ EN\&country Code $=U K R \& \_a d f . c t r l-s t a t e=q f 3 \times 0 c 73 a \_9$. Accessed: 12 Jun. 2019.

INTERNATIONAL LABOR ORGANIZATION. Labour Inspection Convention, n. 81, 1947. Available at: https://www.ilo.org. Accessed: 12 Jun. 2019.

INTERNATIONAL LABOR ORGANIZATION. Labour Inspection (Agriculture) Convention, n. 129, 1969. Available at: https://www.ilo.org. Accessed: 12 Jun. 2019.

INTERNATIONAL LABOR ORGANIZATION. Labour Inspectorates (Non-Metropolitan Territories) Convention, n. 85, 1947. Available at: https://www.ilo.org. Available at: https://www.ilo.org. Accessed: 12 Jun. 2019.
UKRAINE. Law of Ukraine of December 28, 2014. On Amendments to Certain Legislative Acts of Ukraine on Reforming the Compulsory State Social Insurance and Legalization of the Wage Fund. 2014.

UKRAINE. Law of Ukraine, October 14, 1992 № 2694XI. On Labor Protection. Available at: https://zakon. rada.gov.ua/laws/show/2694-12?lang=en. Accessed: 9 Jun. 2019.

PRESENTATION of the Employment Service Reform of June 26, 2015. Available at: http://tsn.ua/ groshi/derzhava-pracevlashtovuvatime-ukrayincivpo-novomu-prezentaciya-reformi-sluzhbi-zaynyatosti-445971.html. 10 Jun. 2019

UKRAINE. Cabinet of Ministers of Ukraine. Regulations on the State Service of Ukraine on Labor, Resolution of the, February 11, 2015 № 96. Available at: https://zakon. rada.gov.ua/laws/show/96-2015-\%D0\%BF?lang=en. Accessed: 9 Jun. 2019.

UKRAINE. [Constitution (1996)]. The Constitution of Ukraine, June 28, 1996 № 254к/96-BP. Available at: https://zakon. rada.gov.ua/laws / show / $254 \%$ D $0 \%$ B A / 96 \%D0\%B2\%D1\%80?lang=en. Accessed: 9 Jun. 2019.

UKRAINE. The Labor Code of Ukraine, on December 10, 1971 № 322-VII. Available at: https://zakon.rada. gov.ua/laws/show/322-08?lang=en.

АНУФРІЕВ, М. І. Зміцнення Аисципліни і законності як фактор Аотримання прав і свобоА громадян у службовій Аіяльності працівників ОВС. Вісник Харківського начіонального університету внутрішніх справ. n. 11, с. 9-12, 2000. Accessed: 9 Jun. 2019.

Богданова О. В. Проблеми використання теорій піраміди травматизму для запобігання нещасним випадкам на виробничтві. Проблеми охорони прачі в Украйні: збірник наукових прачь. Киї: $\triangle \mathrm{У}$ «Національний науковоАосліАний інститут промис Аової безпеки та охорони праці», Вип. 29. 2015. С. 43.

ААРАГАНОВА, Н. В. Сучасний стан правової освіти у сфері управління охороною прачі в Украӥні. Правова освіта в Украйнi: еволюція, сучасний стан, перспективи розвитку: матеріали науково-практичної конференції. Київ: Академія аАвокатури України, 2017. Available at: https://sites.google.com/my.aau. edu.ua/conf-27-04-2017/матеріаци / матеріаличастина-5. Accessed: 10 Jun. 2019. 
3А ОЗНОВА, Ю. С., Брага І. Г. Оцінка стану охорони та безпеки праці й соціальноекономічних насліАків їх незабезпечення у вугільній промисловості України. Економіка промисловості. n. 2, c. 271-279, 2011.

КРУЖИАКО О. Є. Наукові засади оперативного управління охороною прачі: автореф. Аис. ... Аокт. техн. наук: 05.26.01. Київ, 2011. с. 5.

НЕРСЕСЯНЦ В. С. Юриспрудениия. Введение в курс общей теории права и государства: ААя юриАических вузов и факультетов. Москва: НОРМА-ИНФРА·М, 1998. 288 c.

СОРОЧИНСЬКА О. А. Стан охорони прачі в Украйні mа заходи для ї̈ поліпшення. Збірник наукових праць Аержавного економіко-технологічного університету транспорту. Сер.: Транспортні системи і технології. Вип. 24. С. 240-247. 2014.

УКРАЇНЕЦЬ С. Я. Стенограма виступу на Парламентськихслуханнях від 17 листопада 2010 р. «Про стан промислової безпеки та охорони праці». Available at: http://rada.gov.ua/zakon/skl6/11session/ par_sl/sl1711110.htm. Accessed: 10 Jun. 2019.

ХОХОТВІ О. І. Стенограмавиступуна Парламентських слуханнях від 17 мистопада 2010 p. «Про стан промислової безпеки та охорони праці». Available at: http://static.rada.gov.ua/zakon/skl6/11session/ par_sl/sl1711110.htm. Accessed: 10 Jun. 2019.

NATIONAL INSTITUTE FOR STRATEGIC STUDIES. Щодо віАповіАності об’єАнання Аержавної інспекції України з питань праці та Аержавної служби зайнятості України стандартам міжнародної організації праці /. Available at: http://www.niss.gov. ua/articles/1341. 
Para publicar na Revista de Direito Internacional, acesse o endereço eletrônico www.rdi.uniceub.br ou www.brazilianjournal.org.

Observe as normas de publicação, para facilitar e agilizar o trabalho de edição. 